\title{
MENDORONG SIKAP LEBIH BERSAHABAT TERHADAP HUKUM INTERNASIONAL: PENERAPAN HUKUM INTERNASIONAL OLEH PENGADILAN INDONESIA ${ }^{1}$
}

\author{
Ninon Melatyugra \\ Staff Pengajar Fakultas Hukum \\ Universitas Kristen Satya Wacana \\ Korespondensi: ninon.melatyugra@gmail.com
}

\begin{abstract}
Abstrak
Inkonsistensi dan keberagaman cara pandang tentang kedudukan hukum internasional dalam sistem hukum Indonesia merupakan suatu masalah yang harus diselesaikan secara normatif. Artikel ini menawarkan sebuah solusi yang mempreskripsi empat hal penting yang harus dilakukan negara untuk mendorong sikap yang lebih bersahabat terhadap hukum internasional. Preskripsi pertama, memahami hukum internasional sebagai hukum. Kedua, menemukan legitimasi penggunaan hukum internasional dalam konstitusi RI secara kontekstual. Ketiga, mengaktifkan fungsi hakim sebagai interpreter untuk mengaplikasi hukum internasional secara tepat. Keempat, memahami jenis dan karakter hukum internasional beserta cara penerapannya.
\end{abstract}

Kata-kata Kunci: Hukum Internasional; Hukum Nasional; Kedudukan.

\begin{abstract}
Inconsistency and diversity of perspectives on international law in Indonesian legal system are problems that need to be resolved normatively. This article offers a solution which prescribes four significant things for states to be done in order to encourage State to show its friendly attitude to international law. First prescription is to understand that international law is law'. Second prescription is to find contextual legitimacy of using international law by analyzing further the Indonesian Constitution. Third prescription is to activate judges as interpreters to apply international law properly. Fourth prescription is to understand category and character of international law and observe the application.
\end{abstract}

Key Words: International Law; National Law; Status.

${ }^{1}$ Artikel ini pernah dipresentasikan dalam rangka proses seleksi dosen di Fakultas Hukum Universitas Kristen Satya Wacana. 


\section{PENDAHULUAN}

Hukum internasional dalam hukum nasional merupakan isu yang sensitif di Indonesia. Hal tersebut dikarenakan perbedaan perspektif dalam memandang kedudukan hukum internasional dalam hukum nasional. Perbedaan perspektif tersebut kemudian melahirkan inkonsistensi perlakuan hukum internasional dan menciptakan citra Indonesia sebagai negara dengan unfriendly attitude terhadap hukum internasional. Tulisan ini bersifat normatif, dalam arti memberi preskripsi bagaimana seharusnya pengadilan Indonesia mengaplikasikan hukum internasional secara konstitusional. Hal ini sebagai koreksi terhadap praktik pengadilan Indonesia yang tidak konsisten dalam mengaplikasikan hukum internasional: terbelah antara posisi monis dan posisi dualis.

Bagian pertama dalam tulisan ini membahas tentang kerangka teoretikal umum terkait international law before municipal courts sebagai konstruksi dasar dalam memahami hubungan hukum internasional dan hukum. Bagian kedua menjelaskan dua teori tradisional monisme-dualisme yang dominan digunakan untuk menjustifikasi normativitas hukum internasional di wilayah nasional, lebih lanjut akan dijelaskan kelemahan-kelemahan dalam teori tersebut. Bagian ketiga memapar- kan berbagai kasus nasional di Indonesia yang menunjukkan kesimpangsiuran pandangan-pandangan dalam melihat kedudukan hukum internasional di sistem hukum Indonesia. Bagian terakhir akan mengemukakan argumen normatif supaya pengadilan Indonesia lebih pro-aktif dalam mengaplikasikan hukum internasional.

\section{PEMBAHASAN}

\section{Kerangka Teoretikal Umum}

Isu yang akan dibahas pada bab ini adalah hubungan hukum internasional dan hukum nasional, lebih spesifiknya pada peran hukum internasional dalam pengadilan nasional (international law before municipal courts). Lord Bingham mengatakan, "Times have changed. To an extent almost unimaginable even thirty years ago, national courts in this and other countries are called upon to consider and resolve issues turning on the correct understanding and application of international law, not on an occasional basis, now and then, but routinely, and often in cases of great importance." 2

Salah satu faktor utama pengadilan nasional sebagai motorik strategis adalah fungsinya sebagai legitimizing agent. Pengadilan nasional dapat memberikan legitimasi pada tindakan pemerintah dan kebijakan yang dikeluarkannya. ${ }^{3}$ Mengambil contoh Putusan

\footnotetext{
$\overline{2} \quad$ Anthea Roberts, 'Comparative International Law? The Role of National Courts in Creating and Enforcing International Law' (2011) International and Comparative Law Quarterly 57, 57.

Sharon Weill, The Role of National Courts in Applying International Humanitarian Law (Oxford University Press 2014)13.
} 
Mahkamah Konstitusi Republik Indonesia (MK RI) No. 76/PUU-XIII/20154, MK RI menganggap Pasal 55 UU No. 5 Tahun 1986 tentang Peradilan Tata Usaha Negara (PTUN) yang mengatur batas maksimal pengajuan gugatan ke PTUN merupakan open legal policy sehingga Pasal tersebut dinyatakan konstitusional. Selain itu berlaku pula a contrario, pengadilan nasional juga dapat menyatakan sebuah kebijakan pemerintah tidak berlaku (void) sepanjang hakim berpendapat kebijakan tersebut telah melanggar hukum. ${ }^{5}$ Begitu pula kaitannya dengan aplikasi hukum internasional, pengadilan nasional dapat menyatakan suatu kebijakan nasional atau tindakan aktor negara bertentangan dengan hukum internasional.

Salah satu pertanyaan mendasar yang kemudian muncul adalah apakah pengadilan nasional memiliki legitimasi untuk mengajudikasi suatu perkara yang berkaitan dengan hukum internasional. Perlu dipahami terlebih dahulu bahwa secara tekstual, kedudukan hukum internasional di wilayah nasional lazimnya ditemukan secara eksplisit pada konstitusi suatu negara. Konstitusi negara Afrika Selatan ${ }^{6}$ mempreskripsi lembaga peradilan untuk menggunakan pertimbangan hukum internasional dan hukum negara asing untuk menginterpretasi the Bill of
Rights. Hal tersebut menggarisbawahi bahwa ketentuan pada batang tubuh suatu konstitusi menjadi shortcut untuk memberi legitimasi bagi pengadilan nasional dalam rangka pemanfaatan hukum internasional di wilayah nasional sehingga tindakannya sah. Namun demikian, terdapat pula jumlah negara yang tidak sedikit seperti Perancis, Italia, dan Belanda yang mengaplikasi hukum internasional meskipun konstitusi negara-negara tersebut tidak memberi guidelines. ${ }^{7}$

Di sisi lain secara praktik, kedudukan hukum internasional di wilayah nasional sangat didominasi oleh pemikiran monisme dan dualisme. Monisme dan dualisme merupakan dua teori klasik yang menjelaskan normativitas hukum internasional di wilayah nasional. Penjelasan mengenai monisme dan dualisme akan diulas dalam bab selanjutnya.

\section{Paradigma Lama mengenai Norma- tivitas Hukum Internasional di Wilayah Nasional}

Bab ini akan menjelaskan mengenai dua teori tradisional yang sering digunakan dalam menjustifikasi normativitas hukum internasional di wilayah nasional. Secara singkat, skema pemikiran teori monisme-dualisme dapat dilihat melalui bagan 1 .

\footnotetext{
Putusan Mahkamah Konstitusi Republik Indonesia Nomor 76/PUU-XIII/2015, Mahkamah Konstitusi, 15 Juni 2016.

5 Lihat contoh Putusan Mahkamah Konstitusi Republik Indonesia Nomor 011-017/PUU-I2003, Mahkamah Konstitusi, 24 Februari 2014. Putusan tersebut memulihkan right to vote dan right to be candidate dari bekas anggota PKI.

$6 \quad$ Article 39 (1) South African Constitution.

7 Hannes Vallikivi, 'Domestic Applicability of Customary International Law in Estonia' (2002) 7 Juridica International 28, 30.
} 
Bagan 1 Monisme-Dualisme

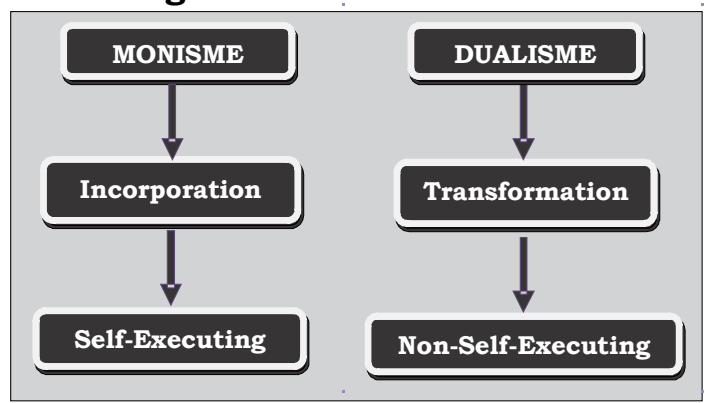

Teori monisme berasal dari mahzab natural law ${ }^{8}$. Secara garis besar, aliran monisme berprinsip hukum internasional adalah konsekwensi langsung dari norma dasar seluruh hukum ${ }^{9}$ sehingga mengikat setiap individu secara kolektif ${ }^{10}$. Oleh karena pemikiran tersebut melihat hukum internasional dan hukum nasional sebagai satu kesatuan 'tubuh' pengetahuan yang dinamakan hukum ${ }^{11}$, maka monisme menggunakan teknik incorporation dimana negara dapat menerapkan hukum internasional di wilayah nasional tanpa mengubah dasar hukumnya. ${ }^{12}$ Teknik incorporation memberi implikasi terciptanya jenis treaty yakni selfexecuting treaty yang bersifat dapat diterapkan secara langsung dalam sistem hukum nasional. ${ }^{13}$
Teori dualisme memberi supremasi pada hukum nasional berdasarkan kedaulatan negara sehingga hukum internasional tidak dapat memaksa suatu negara patuh terhadap hukum internasional. ${ }^{14}$ Berbeda dengan teori monisme yang melihat hukum internasional sebagai satu kesatuan dengan hukum nasional, teori dualisme menempatkan hukum internasional terpisah dengan hukum nasional ${ }^{15}$ (International law is not ipso facto part of municipal law $\left.{ }^{16}\right)$. Oleh karena terdapat pemisahan tegas antara kedua jenis hukum tersebut, maka teori dualisme menggunakan teknik transformation dimana penerapan hukum internasional harus diikuti dengan proses legislasi untuk mengubah hukum internasional menjadi bagian dari hukum nasional. ${ }^{17}$ Teknik transformasi ini menghasilkan jenis hukum yang bersifat non-self-executing treaty dimana jenis tersebut tidak akan memiliki daya eksekusi tanpa aturan tambahan atau aturan pelaksana nasional. ${ }^{18}$

Kedua teori klasik tersebut nyatanya memiliki kelemahan-kelemahan krusial dalam memberikan normativitas

\footnotetext{
8 Basak Cali, The Authority of International Law: Obedience, Respect, and Rebuttal (Oxford University Press 2015) 137.

Martin Dixon, Textbook on International Law (Blackstone Press Limited 1993) 69.

Sugeng Istanto, Hukum International (Universitas Atma Jaya Yogyakarta 2010) 7.

Martin Dixon, Loc.Cit.

Damos Dumoli Agusman, Treaties Under Indonesian Law: A Comparative Study (Remaja Rosdakarya 2014) 85 .

$13 \quad$ Ibid, 101.

14 Anthony D’Amato, 'The Coerciveness of International Law' (2010) 91 Faculty Working Papers $<$ http://scholarlycommons.law.northwestern.edu/cgi/viewcontent.cgi?article=1090\&context= facultyworkingpapers> diakses 18 Juli 2016.

15 Werner Levi, Contemporary International Law: A Concise Introduction (Westview Press 1991), 23. Martin Dixon, Op.Cit. 74.

Damos Dumoli Agusman, Op.Cit. 91.

Ibid, 107.
} 
dalam penggunaan hukum internasional di wilayah nasional. ${ }^{19}$ Pertama, teori tersebut bersifat expostyang hanya melihat pada praktik-praktik negara saja. Kedua, teori tersebut kurang mengandung normative content yang tidak dapat digunakan sebagai argumen di pengadilan nasional. Ketiga, teori tersebut tidak mampu menghadapi praktik overlapping terhadap teori itu sendiri di suatu negara.

Berbagai masalah nasional yang mencerminkan ketidakmemadaian teori monisme-dualisme seperti yang telah dijelaskan di atas dalam memberikan solusi dan normativitas hukum internasional akan dibahas dalam bab berikutnya.

\section{Berbagai Masalah Nasional Terkait Aplikasi Hukum Internasional di Wilayah Indonesia}

Bab ini akan memaparkan berbagai kasus yang terjadi di Indonesia dimana terdapat simpang siur dalam memandang kedudukan hukum internasional dalam wilayah nasional. Hal tersebut menimbulkan inkonsistensi keseragaman perlakuan terhadap hukum internasional oleh state agents, terkhususnya pengadilan nasional.

Dalam tulisannya, Simon Butt menunjukkan bahwa Indonesia rentan mengalami overlapping. Kesimpangsiuran para ahli dan praktisi hukum dalam memandang posisi hukum internasional di wilayah nasional disebabkan mereka sangat didominasi oleh pemikiran teori tradisional monismedualisme.

Kalangan monistakan menganggap Indonesia adalah negara monist. Pertama ${ }^{20}$, Damos Dumoli Agusman mengatakan bahwa Undang-Undang No. 24 Tahun 2000 tentang Perjanjian Internasional (yang sering kali dijadikan argumen untuk menolak proses inkorporasi) tidak ditujukan untuk mengklarifikasi status perjanjian internasional yang diratifikasi oleh Indonesia, oleh sebab itu, adanya UndangUndang a quo tidak lantas menjadi preskripsi kewajiban negara untuk melakukan proses transformasi. Kedua ${ }^{21}$, Mahkamah Agung dalam praktiknya guna menyelesaikan kasus Kedutaan Arab di Indonesia, telah menggunakan prinsip diplomatic community pada Article 31 the 1961 Vienna Convention on Diplomatic Relations yang notabene ketentuan tersebut belum ditransformasi ke dalam hukum internasional pada saat itu. Kedua hal di atas menunjukkan bahwa Indonesia adalah negara monist dalam perspektif teori monismedualisme.

Di sisi yang berseberangan, kalangan dualist menyebut Indonesia sebagai negara dualist. ${ }^{22}$ Pertama, ratifikasi the United Nations Convention on the Law

\footnotetext{
$19 \quad$ Ninon Melatyugra, 'Normativitas Hukum Internasional dalam Praktik Pengujian Undang-Undang oleh Mahkamah Konstitusi' (tesis, Universitas Kristen Satya Wacana 2016).

20 Simon Butt, 'The Position of International Law Within The Indonesian Legal System' (2014) 28 Emory International Law Review 1, 7-9.

21 Ibid.

22 Ibid.
} 
of the Sea (UNCLOS) ke dalam UU No. 17 Tahun 1985 dianggap tidak serta merta mengganti UU No. 4 Tahun 1960 tentang Perairan Indonesia sampai 10 tahun kemudian muncul UU No. 6 Tahun 1996 yang mengotorisasi keberlakuan UNCLOS tersebut. Kedua, dalam satu lembaga peradilan yang sama yakni Mahkamah Agung menolak ${ }^{23}$ penerapan the 1958 New York Convention on Recognition and Enforcement of Foreign Arbitral Awards meski pada saat itu telah diratifikasi melalui Keputusan Presiden No. 34 Tahun 1981. Argumen penolakan tersebut didasarkan atas belum adanya peraturan pelaksananya.

Overlapping yang tergambar di atas menunjukkan situasi riil inkonsistensi perlakuan hukum internasional di wilayah nasional yang disebabkan oleh pengkotak-kotakan teori monismedualisme. Masalah ini patut menjadi perhatian besar bagi pemerintah karena berimbas pada keraguan dunia internasional terhadap tingkat kepatuhan Indonesia terhadap hukum internasional. Ketika Indonesia tidak dapat menunjukkan konsistensinya dalam melaksanakan kewajiban internasional sesuai dengan hukum internasional, maka hal tersebut akan mempersempit peluang terciptanya strategic interaction antara negara Indonesia dengan negara lain. Juga perlu dipahami bahwa teori monisme-dualisme tidak mampu untuk memberi solusi yang memadai terhadap persoalan demikian karena teori tersebut hanya bersifat deskriptif ("is" statement), sedangkan dibutuhkan solusi yang bersifat normatif ("ought" statement). Dengan kata lain, pendekatan teori monisme-dualisme tidak dapat digunakan untuk menyelesaikan suatu perkara. ${ }^{24}$

Solusi normatif yang ditawarkan dalam tulisan ini akan dipaparkan secara mendalam dalam bab berikutnya.

\section{Sikap Pengadilan Nasional yang Lebih Bersahabat terhadap Hukum Inter- nasional: Argumen Normatif}

Bab ini akan membahas mengenai tawaran solusi normatif untuk mengatasi permasalahan nasional terkait aplikasi hukum internasional dalam sistem hukum nasional, terkhususnya pengadilan nasional.

Keberagaman perspektif dalam memandang posisi hukum internasional dalam wilayah hukum internasional yang telah terlanjur menjamur di Indonesia menyebabkan hubungan yang saling kontradiktif di antara dua bidang yaitu hukum internasional dan hukum nasional sehingga menimbulkan potensi kerugian bagi Indonesia. Suatu solusi diperlukan untuk membangun kembali hubungan kedua bidang hukum tersebut supaya keduanya dapat berjalan selaras dan Indonesia segera meninggalkan citra

23 PT. Nizwar vs. Navigation Maritime Bulgare, No. 2944K/PDT/1983, Mahkamah Agung, 29 November 1984.

24 Lord Steyn dalam kasus The Tin Council Case. Martin Dixon, Textbook on International Law: Seventh Edition (Oxford University Press 2007) 94. 
'unfriendly attitude' terhadap hukum internasional ${ }^{25}$.

Sebuah solusi yang ditawarkan memiliki substansi dengan goal membentuk Indonesia menjadi a friendly state toward international law dengan memberi preskripsi-preskripsi sebagai berikut: Pertama, memahami bahwa "international law is law". Ketika berbicara mengenai konsep "international law is law" maka isu ini berada dalam bangunan teori natural law dimana ia merupakan persimpangan di antara hukum dan moral ${ }^{26}$ yang berlaku secara universal ${ }^{27}$. Hukum internasional memiliki setidaknya 4 nilai yang menjadi constitutive elements untuk disebut sebagai hukum, yakni: ${ }^{28}$

a. Law has the capacity to give rise to events in the world (law's efficacy), Austin mengatakan bahwa bentuk hukum tanpa kekuatan untuk mengaktualkan suatu hal tidak bisa disebut sebagai hukum. ${ }^{29}$ Argumen Austin tersebut merupakan pandangan yang hanya bersifat mekanisme dan tidak dapat digunakan untuk justifikasi. Dalam kasus The Barrier, ICJ memerintahkan Israel harus memindahkan pagar batas negara dari West Bank, dan Israel menolak. Beberapa waktu kemudian, the Israeli High Court menerapkan putusan yang bunyinya sama untuk memerintah- kan pemerintah Israel memindahkan pagar batas negara dari komunitas Palestina dan Israel mematuhinya. Nampak bahwa hukum internasional dalam kasus The Barrier memiliki kekuatan eksekusi pada saat ia berada di Mahkamah Agung Israel dan kehilangan kekuatannya saat berada di ICJ. Ini adalah masalah mekanisme. Hukum internasional tetap dapat memiliki kekuatan untuk mengaktualkan meskipun ia harus membutuhkan bantuan pengadilan nasional sebagai law agents.

b. It obligates as a matter of legitimate authority (law's normativity); Ketika hukum internasional mewajibkan, maka ia dipandang sebagai otoritas yang sah. Prinsip umum hukum merupakan salah satu bentuk hukum internasional yang tidak hanya berbicara namun juga mengikat ("The principle is not just talk. It appears to bind." ${ }^{30}$ ). Beberapa prinsip hukum seperti non-annexation, national self-defense, discrimination memiliki otoritas seperti hukum. Prinsip-prinsip hukum di atas tidak memerlukan state's consent untuk mendapatkan keberlakuan. Selama prinsip-prinsip hukum tersebut applicable untuk diterapkan dalam situasi tertentu, maka prinsip-prinsip

\footnotetext{
$25 \quad$ Mahmudin Nur Al-Gozaly, 'The Judicial Expansive Attitude Towards Public Policy In Enforcement of Foreign Arbitral Awards In Indonesia' (2014) 15 Jurnal Opinio Juris 127, 128.

26 Raymod Wacks, Philosophy of Law: A Very Short Introduction (Oxford University Press 2006$) 1$. Ibid, 3.

28 Joshua Kleinfeld, 'Skeptical Internationalism: A Study of Whether International Law Is Law' (2010) 78 Fordham Law Review 2451, 2451.

$29 \quad$ Ibid, 2506.

$30 \quad$ Ibid, 2015.
} 
hukum tersebut mempunyai daya wajib sebagai otoritas yang sah.

c. It obligates as a matter of moral rationality (normativity again); Artinya hukum internasional mewajibkan seperti moral rationality. Hukum internasional memiliki posisi yang seimbang dengan hukum nasional, dan bukan suicide pact. Hukum internasional memiliki tujuan moral dan tidak diartikan sebagai klaim untuk bebas dari semua kewajiban, tetapi sebagai hak setiap orang berbuat apa yang selayaknya benar, dan memberi tugas pada pemimpin negara untuk melakukan apa yang seharusnya dilakukan untuk masyarakatnya. Hukum internasional bekerja di bawah konstelasi nilainilai, sehingga apabila ia bekerja di luar nilai-nilai maka ia tidak dapat disebut sebagai hukum.

d. It maintains a character distinct from the political or partisan (law's objectivity). Politikal yang dimaksud adalah "resolving cases according to as open-ended and discretionary a mix of consideratios, moral, prudential,..."'1, sedangkan partisan adalah menjadi terikat pada partai politik tertentu secara emosional dan intelektual. ${ }^{32}$ Dalam hal ini, hukum internasional memiliki karakter nonpartisanship yang berbeda dengan political dan partisipan. Contoh, Mahkamah
Agung Amerika Serikat dalam kasus Roper vs. Simmons menyatakan pendapat bahwa eksekusi di bawah 18 tahun merupakan inkonstitusional. Pengadilan tersebut memperlihatkan tindakan yang tidak menelan mentah kata secara langsung, tetapi merujuk pada pemahaman historis terhadap konstitusi, juga menggunakan prinsip apolitical yakni stare decisis, bahwa mengijinkan eksekusi terhadap orang di bawah 18 tahun dianggap sebagai putusan yang political.

Ulasan singkat di atas menyimpulkan bahwa hukum internasional memiliki karakter hukum atau singkatnya, "international law is law" yang memiliki daya normatif sama dengan hukum nasional.

Kedua, menemukan legitimasi penggunaan hukum internasional dalam Konstitusi RI secara kontekstual.

Seperti yang telah disebutkan sebelumnya, kedudukan hukum internasional dalam wilayah nasional biasanya dilihat dari konstitusi negara tersebut. Konstitusi Afrika Selatan disebut sebagai salah satu konstitusi paling progresif ${ }^{33}$ karena menjelaskan kedudukan hukum internasional dalam sistem hukum nasionalnya. Hal berbeda dialami oleh Indonesia karena Undang-Undang Dasar Negara Republik Indonesia Tahun 1945 (UUD NRI 1945)

Ibid, 2523.

Ibid.

33 Henning Melber, 'Constitutionalism In Democratic South Afrika: Celebrations, Contestations, and Challenges' (2013) 36 Strategic Review for Southern Africa 203, 203. 
tidak mengatur ketentuan eksplisit tersebut pada batang tubuhnya. ${ }^{34}$

Konsep international constitution yang digagas Sarah H. Cleveland memberi solusi terhadap masalah ketiadaan otorisasi tertulis pada konstitusi. Konsep ini pada dasarnya menjelaskan sumber legitimasi bagi penggunaan hukum internasional melalui 3 cara. Pertama, melihat pada konstitusi seperti South African Constitution. ${ }^{35}$ Kedua, melihat pada keinginan implisit dari konstitusi. Ketiga, melihat fungsi penggunaan hukum internasional untuk memperkuat ketentuan mengenai hak asasi manusia. ${ }^{36}$

Perlu dipahami bahwa suatu konstitusi tidak dapat dimaknai secara sempit. ${ }^{37}$ Terdapat konstitusi yang tidak tertulis yaitu nilai-nilai yang hidup dalam praktik-praktik ketatanegaraan ${ }^{38}$ seperti Inggris yang tidak memiliki konstitusi formal atau written constitution, namun tidak diartikan kemudian bahwa ia tidak memiliki konstitusi. ${ }^{39}$ Artinya, konstitusi di sini dipahami secara beyond the text itself.

Melalui konsep International Constitution, legitimasi penggunaan hukum internasional di Indonesia ditemukan dalam semangat pendiri negara Indonesia untuk berlaku sesuai dengan hukum internasional. Hal tersebut tercermin pada Pembukaan UUD NRI 1945, Naskah Persiapan UUD NRI 1945, serta Pidato Pancasila. ${ }^{40}$ Dokumen-dokumen tersebut menunjukkan adanya keinginan negara Indonesia untuk berlaku sesuai hukum internasional sehingga hal tersebut yang menjadi kausa halal penggunaan hukum internasional di Indonesia.

Supaya pemanfaatan hukum internasional tidak berlaku abusive, konsep international constitution memberi ramburambu bagi pengadilan nasional. ${ }^{41}$ Pertama, pengadilan perlu melihat pada penerimaan sistem konstitusional suatu negara dalam mempertimbangkan aturan internasional. Kedua, seberapa baik suatu norma internasional terjabarkan dan diterima secara universal. Ketiga, kriteria pembatasanpembatasan di dalam hukum internasional itu sendiri. Dengan ketiga hal di atas, maka pengadilan diharapkan dapat menyaring aturan-aturan internasional mana yang dapat diterapkan dalam wilayah nasional.

Ketiga, Mengaktifkan fungsi hakim sebagai interpreter untuk mengaplikasi

\footnotetext{
UUD NRI 1945 hanya menyebutkan kewenangan membuat perjanjian internasional.

Sarah H. Cleveland, 'Our International Constitution' (2006) 31 The Yale Journal of International Law 1,7 .

37 UUD sebagai konstitusi dalam arti sempit ini pada hakikatnya merupakan "a politico-legal document" (suatu dokumen hukum politik). A. Mukthie Fadjar, Konstitusionalisme Demokrasi: Sebuah Diskursus tentang Pemilu, Otonomi Daerah dan Mahkamah Konstitusi sebagai Kado untuk 'Sang Penggembala' (In-TRANS Publishing 2010) 15.

38 Jimly Asshiddiqie, Hukum Acara Pengujian Undang-Undang Cetakan II (Sinar Grafika, 2012) 6.

39 Titon Slamet Kurnia, Konstitusi HAM: Undang-Undang Dasar Negara Republik Indonesia Tahun 1945 \& Mahkamah Konstitusi Republik Indonesia (Fakultas Hukum UKSW 2013) 10-11.

$40 \quad$ Ninon Melatyugra, Loc.Cit.

41 Sarah H. Cleveland, Op.Cit. 107.
}

$36 \quad$ Ibid, 63. 
hukum internasional secara tepat. Hukum internasional sekurang-kurangnya memiliki peran sebagai alat bantu (interpretive tool) dalam interpretasi konstitusi. ${ }^{42}$ Dalam arti sepanjang dalam hukum internasional ditemukan kaidah lebih baik (misalnya memberikan efek perlindungan HAM lebih kuat) maka hal itu dapat digunakan oleh pengadilan sebagai gap-filler konstitusi Indonesia.

Konsep Transnational Legal Process yang digagas Harold Hongju Koh menggambarkan bagaimana aktor publik dan privat-negara, organisasi internasional, perusahaan multi-nasional, NGO, perorangan berinteraksi dalam ruang publik dan privat, domestik dan internasional, untuk membuat, menginterpretasi, melaksanakan, dan akhirnya menginternalisasi aturan hukum internasional. ${ }^{43}$ Tiga tahap proses hukum transnasional adalah interaksi, interpretasi, dan internalisasi yang memungkinkan "vertical domestication" ${ }^{44}$ terjadi. Bentuk interaksi tercermin dalam contoh kasus Thompson v. Oklahoma, dimana Justice John Paul Stevens membatalkan hukuman mati untuk terpidana berumur 15 tahun dengan melihat pada larangan eksekusi minor di Soviet Union dan negara-negara Eropa Barat. ${ }^{45}$ Interaksi tersebut kemudian diikuti dengan interpretasi terhadap nilai-nilai dalam hukum internasional yang applicable. Selanjutnya dilanjutkan dengan internalisasi atau keberlakuan dari nilainilai yang telah diinterpretasi tersebut.

Pada saat hakim memanfaatkan hukum internasional, ia mencerminkan perilaku compliance yang dipengaruhi oleh 3 faktor keuntungan yakni reputation, reciprocity, dan retaliation (Three $R$ 's of Compliance ${ }^{46}$ ). Teori tersebut berasumsi rasional bahwa kepatuhan hukum internasional lebih menguntungkan ketimbang ketidakpatuhan.

Transnational legal process tidak mengambil posisi defference secara mutlak pada hukum internasional tetapi dalam posisi yang proporsional sejalan dengan a decent respect to the opinions of mankind. Teori ini juga sebenarnya mendorong hakim pengadilan nasional untuk bersikap kritis menginterpretasi terhadap hukum internasional. Seorang hakim harus memutuskan, dan memberikan interpretasi konstitusi yang terbaik bagi kepentingan paling mendasar yang harus dilindunginya. Artinya, apabila hakim menemukan hukum internasional tersebut tidak applicable maka hakim harus mem-filter norma tersebut.

$\overline{42}$ Titon Slamet Kurnia, 'Interpretasi Hak-Hak Asasi Manusia oleh Mahkamah Konstitusi Republik Indonesia Melalui Pengujian Undang-Undang' (Disertasi: Program Doktor Ilmu Hukum Fakultas Hukum Universitas Airlangga 2014) 151.

43 Harold Hongju Koh, 'International Law as Part of Our Law' (2004) 98 American Journal of International Law 43,55.

44 Vertical Domestication adalah proses norma hukum internasional ditarik ke dalam sistem hukum domestik. Harold Koh, '1998 Frankel Lecture: Bringing International Law Home' (1998) 35 Houston Law Review 623, 626.

$45 \quad$ Ibid, 46.

46 Andrew T. Guzman, How International Law Works: A Rational Choice Theory (Oxford University Press 2008) 33-34. 
Keempat, Memahami jenis dan karakter hukum internasional beserta cara penerapannya. Hukum internasional memiliki 5 jenis yaitu: perjanjian internasional, hukum kebiasaan internasional, prinsip umum hukum, putusan pengadilan, dan pendapat para ahli. ${ }^{47}$ Kelima jenis hukum internasional tersebut mempunyai cara perlakuannya masing-masing.

a. Perjanjian Internasional. Perjanjian internasional adalah "an international agreement concluded between States in written form and governed by international law, whether embodied in a single instrument or in two or more related instruments and whatever is particular designation." ${ }^{38}$ Di Indonesia, daya keterikatan perjanjian internasional belum dipandang seragam $^{49}$. Simon Butt telah mengutarakan masalah-masalah terkait perjanjian internasional yang telah diratifikasi, namun belum ada transformasi ke bentuk nasional dianggap tidak memiliki daya ikat. Hendaknya terhadap perlakuan terhadap perjanjian internasional, harus dilihat terlebih dahulu apakah perjanjian internasional tersebut self-executing atau non-self-executing, mencontoh pada praktik di Amerika Serikat. Artinya ketika suatu perjanjian internasional sudah diratifikasi, itu sebagai bentuk consent negara kecuali ditentukan bahwa perjanjian internasional tersebut adalah non-self-executing yang membutuhkan peraturan pelaksana lebih lanjut. Penyangkalan terhadap keterikatan perjanjian internasional yang bersifat selfexecuting yang telah diratifikasi akan menciptakan citra unfriendly attitude terhadap hukum internasional.

b. Hukum Kebiasaan Internasional. Hukum kebiasaan internasional adalah " a customary prac-tice of states followed from a sense of legal obligation." 50 Terhadap jenis hukum internasional ini, praktik negara Jerman dapat menjadi contoh. Article 25 Germany Grungesetz menyatakan bahwa aturan umum hukum internasional publik adalah bagian terintegrasi hukum federal. Dapat dikatakan bahwa hukum kebiasaan internasional yang universal diinkorporasi ke dalam sistem hukum internasional.

Apabila dalam litigasi, keraguan terhadap hukum kebiasaan internasional muncul mempertanyakan apakah hukum yang direferensi secara langsung menciptakan hak dan kewajiban bagi individu, maka pengadilan perlu mendapat putusan

\section{Article 38 (1) ICJ Statute.}

Article 2 (1(a)) Vienna Convention on the Law of Treaties.

49 Contoh pada isu ratifikasi internal dan ratifikasi eksternal. Damos Dumoli Agusman, Hukum Perjanjian Internasional: Kajian Teori dan Praktik Indonesia (Refika Aditama 2010) 76-78.

50 Jack Goldsmith dan Eric A. Posner, 'A Theory of Customary International Law' 63 John M. Olin Law \& Economics Working Paper <http://www.law.uchicago.edu/files/files/63.GoldsmithPosner.pdf> Diakses 21 Juli 2016. 
dari pengadilan konstitusional federal. ${ }^{51}$ Norm-verification procedure ini akan mengeluarkan putusan tentang interpretasi terhadap Konstitusi dan putusan tersebut dapat diaplikasi pada pengadilan awal untuk memutus hasil perkara.

Indonesia dapat mencontoh perlakuan hukum kebiasaan internasional di Jerman. Dengan menggunakan fasilitas pengujian konstitusional di MK RI, hakim di pengadilan dapat memastikan apakah hukum kebiasaan internasional yang dipakai sudah konstitusional atau belum sehingga pemanfaatan hukum internasional tidak berlaku abusive terhadap UUD NRI 1945.

c. Prinsip Umum Hukum. Sama halnya dengan hukum kebiasaan internasional, prinsip umum hukum hendaknya diperlakukan secara inkorporasi. Shaw berpendapat:

"In such instances the judge will proceed to deduce a rule that will be relevant, by analogy from already existing rules or directly from the general principles that guide the legal system, whether they be referred to as emanating from justice, equity or considerations of public policy'. A controversial aspect of the general principles of law is that, unlike treaties and custom, they do not have a consensual basis." ${ }^{2}$
Artinya, selama terdapat prinsip umum hukum yang relevan diterapkan dalam suatu kasus, maka prinsip umum hukum tersebut dapat digunakan. Seperti contoh prinsip non-refoulement yang merupakan prinsip utama dalam hukum refugee untuk mewajibkan negara tidak memulangkan refugee ke negara asalnya dalam situasi yang dapat membahayakan keselamatan refugee. ${ }^{53}$ Prinsip hukum tersebut berlaku sebagai complicity principle atau jus cogens $^{54}$ juga diatur dalam Article 33 Konvensi Refugee 1951.

d. Putusan Pengadilan. Putusan pengadilan merupakan salah satu subsidiary means dalam sumber hukum internasional. Meski sifatnya subsidiary, tidak berarti putusan pengadilan tidak penting. Praktiknya, International Court of Justice secara konsisten menggunakan putusan-putusan ICJ sebelumnya dan kebanyakan tribunal internasional memanfaatkan putusan-putusan baik internasional dan nasional. ${ }^{55}$

Terhadap putusan pengadilan, pemanfaatannya disarankan secara inkorporasi dengan memperhatikan kemampuan hakim untuk mengiden-

51 Dinah Shelton, International Law and Domestic Legal System: Incorporation, Transformation, and Persuasion (Oxford University Press 2014) 44.

52 Institute for Security Studies, Curriculum on International Criminal Justice (Institute for Security Studies 2012) 17.

53 Guy S Goodwin-Gill, 'Editorial: The Dynamic of International Refugee Law' (2014) 25 International Journal of Refugee Law 651, 652.

54 Stephen H. Legomsky, 'Secondary Refugee Movements and the Return of Asylum Seekers to Third Countries: The Meaning of Effective Protection' (2013) 15 International Journal of Refugee Law 567, 568.

55 Christopher Greenwood, 'Sources of Law: An Introduction' < http://legal.un.org/avl/pdf/ls / greenwood_outline.pdf> Diakses 23 Juli 2016. 
tifikasi putusan-putusan pengadilan yang relevan dengan kasusnya.

e. Pendapat Para Ahli. Aplikasi secara inkorporasi juga disarankan pada sumber hukum internasional yang terakhir ini. 'The teaching of the most highly qualified publicists' ini bersifat pedoman persuasif. ${ }^{56}$ Sepanjang pendapat para ahli tersebut relevan dan rasional terhadap suatu kasus, maka tidak diperlukan suatu prosedur khusus untuk memperlakukannya.

\section{PENUTUP}

Pada akhirnya tulisan ini menyimpulkan bahwa:

1. Teori klasik monisme-dualisme sudah tidak relevan lagi dalam menjustifikasi karena pertama, teori tersebut bersifat ex-post yang hanya melihat pada praktik-praktik negara saja. Kedua, teori tersebut kurang mengandung normative content yang tidak dapat digunakan sebagai argumen di pengadilan nasional. Ketiga, teori tersebut tidak mampu menghadapi praktik overlapping terhadap teori itu sendiri di suatu negara.

2. Suatu solusi normatif dibutuhkan untuk mendorong negara bersikap lebih ramah terhadap hukum internasional supaya doctrinal disputes yang menciptakan inkonsistensi dan keberagaman perlakuan terhadap hukum internasional dapat teratasi.

56 Ibid.
Solusi tersebut dilakukan dengan mengambil teori International Constitution untuk memberi legitimasi terhadap hukum internasional dalam tataran nasional yakni melihat pada UUD NRI 1945. Teori kedua yang dipakai adalah transnational legal process untuk memberi pedoman bagi hakim di pengadilan dalam mengaplikasi hukum internasional secara tepat.

3. Tulisan ini juga memberi eksplanasi tentang bagaimana negara seharusnya memperlakukan hukum internasional sesuai dengan masingmasing karakter jenis hukum internasional. Setiap jenis hukum internasional memiliki karakter yang berbeda sehingga perlakuan terhadap setiap jenis tersebut haruslah berbeda pula.

\section{DAFTAR BACAAN}

\section{Buku}

Agusman, Damos Dumoli, Hukum Perjanjian Internasional: Kajian Teori dan Praktik Indonesia (Refika Aditama 2010).

Agusman, Damos Dumoli, Treaties Under Indonesian Law: A Comparative Study (Remaja Rosdakarya 2014).

Asshiddiqie, Jimly, Hukum Acara Pengujian Undang-Undang Cetakan II (Sinar Grafika, 2012).

Cali, Basak, The Authority of International Law: Obedience, Respect, and Rebuttal (Oxford University Press 2015). 
Dixon, Martin, Textbook on International Law (Blackstone Press Limited 1993).

Dixon, Martin, Textbook on International Law: Seventh Edition (Oxford University Press 2007).

Fadjar, A. Mukthie, Konstitusionalisme Demokrasi: Sebuah Diskursus tentang Pemilu, Otonomi Daerah dan Mahkamah Konstitusi sebagai Kado untuk 'Sang Penggembala' (InTRANS Publishing 2010).

Guzman, Andrew T. How International Law Works: A Rational Choice Theory (Oxford University Press 2008).

Institute for Security Studies, Curriculum on International Criminal Justice (Institute for Security Studies 2012)

Istanto, Sugeng, Hukum International (Universitas Atma Jaya Yogyakarta 2010).

Kurnia, Titon Slamet, Konstitusi HAM: Undang-Undang Dasar Negara Republik Indonesia Tahun 1945 \& Mahkamah Konstitusi Republik Indonesia (Fakultas Hukum UKSW 2013).

Levi, Werner, Contemporary International Law: A Concise Introduction (Westview Press 1991).

Shelton, Dinah, International Law and Domestic Legal System: Incorporation, Transformation, and Persuasion (Oxford University Press 2014).

Wacks, Raymod, Philosophy of Law: A Very Short Introduction (Oxford University Press 2006).
Weill, Sharon, The Role of National Courts in Applying International Humanitarian Law (Oxford University Press 2014).

\section{Jurnal}

Al-Gozaly, Mahmudin Nur, 'The Judicial Expansive Attitude Towards Public Policy In Enforcement of Foreign Arbitral Awards In Indonesia' (2014) 15 Jurnal Opinio Juris.

Butt, Simon, 'The Position of International Law Within the Indonesian Legal System' (2014) 28 Emory International Law Review.

Cleveland, Sarah H., 'Our International Constitution' (2006) 31 The Yale Journal of International Law.

Goodwin-Gill, Guy S, 'Editorial: The Dynamic of International Refugee Law' (2014) 25 International Journal of Refugee Law.

Kleinfeld, Joshua, 'Skeptical Internationalism: A Study of Whether International Law Is Law' (2010) 78 Fordham Law Review.

Koh, Harold, '1998 Frankel Lecture: Bringing International Law Home' (1998) 35 Houston Law Review.

Koh, Harold Hongju International Law as Part of Our Law' (2004) 98 American Journal of International Law.

Legomsky, Stephen H., 'Secondary Refugee Movements and the Return of Asylum Seekers to Third Countries: The Meaning of Effective Protection' (2013) 15 International Journal of Refugee Law. 
Melber, Henning, 'Constitutionalism In Democratic South Afrika: Celebrations, Contestations, and Challenges' (2013) 36 Strategic Review for Southern Africa.

Roberts, Anthea, 'Comparative International Law? The Role of National Courts in Creating and Enforcing International Law' (2011) International and Comparative Law Quarterly.

Vallikivi, Hannes, 'Domestic Applicability of Customary International Law in Estonia' (2002) 7 Juridica International.

\section{Internet}

D'Amato, Anthony, The Coerciveness of International Law' (2010) 91 Faculty Working Papers <http:// scholar 1 y com mons.1aw. northwestern.edu/cgi / viewcontent.cgi? article $=1090 \%$ context $=$ faculty working papers $>$ diakses 18 Juli 2016.

Goldsmith, Jack dan Eric A. Posner, 'A Theory of Customary International Law' 63 John M. Olin Law \& Economics Working Paper <http:// www.law.uchicago.edu/files/files / 63.Goldsmith-Posner.pdf> diakses pada tanggal 21 Juli 2016.

Greenwood, Christopher, 'Sources of Law: An Introduction'<http:/ /legal.un.org/ avl/pdf/ls/greenwood_outline.pdf> diakses 23 Juli 2016.

\section{Tesis/Disertasi}

Kurnia, Titon Slamet 'Interpretasi HakHak Asasi Manusia oleh Mahkamah
Konstitusi Republik Indonesia Melalui Pengujian Undang-Undang' (Disertasi, Program Doktor Ilmu Hukum Fakultas Hukum Universitas Airlangga 2014).

Melatyugra, Ninon, 'Normativitas Hukum Internasional dalam Praktik Pengujian Undang-Undang oleh Mahkamah Konstitusi'(Tesis, Universitas Kristen Satya Wacana 2016).

\section{Putusan Pengadilan}

PT. Nizwar vs. Navigation Maritime Bulgare, No. 2944K/PDT/1983, Mahkamah Agung, 29 November 1984.

Putusan Mahkamah Konstitusi Republik Indonesia Nomor 011-017/PUUI2003, Mahkamah Konstitusi, 24 Februari 2014.

Putusan Mahkamah Konstitusi Republik Indonesia Nomor 76/PUU-XIII/ 2015, Mahkamah Konstitusi, 15 Juni 2016.

\section{Peraturan}

International Court of Justice Statute.

South African Constitution.

Undang-Undang Dasar Negara Republik Indonesia Tahun 1945.

Vienna Convention on the Law of Treaties. 
